\title{
Hubungan kadar leukosit dengan severitas lesi pembuluh darah koroner pada pasien sindrom koroner akut di RSUP Prof. Dr. R. D. Kandou periode Juli-September 2015
}

\author{
${ }^{1}$ Lucky A. Tulung \\ ${ }^{2}$ Agnes L. Panda \\ ${ }^{2}$ Starry H. Rampengan
}

\author{
${ }^{1}$ Kandidat Skripsi Fakultas Kedokteran Universitas Sam Ratulangi Manado \\ ${ }^{2}$ Bagian Kardiologi Fakultas Kedokteran Universitas Sam Ratulangi Manado \\ Email: luckytulung12088@gmail.com
}

\begin{abstract}
Acute Coronary Syndrome (ACS) is a set of manifestations or symptoms of coronary artery disease and thrombosis which can threaten the patien's life due to interfering the blood supply of heart muscle. The infarct size is determined by assessing the coronary arteries lesion, stenosis. This study was aimed to determine the relationship between levels of leukocytes and the severity of coronary arteries lesions in patients with ACS. This was a descriptive analytical study with a cross-sectional retrospective design. The modified Gensini score was used to assess the severity of coronary artery lesion. The first leukocyte count examined when the patients was admitted to the hospital was obtained from the medical records period July to September 2015. Data were analyzed by using SPSS 20.0. The Pearson correlation test showed no significant relationship between the levels of leukocytes and the severity of coronary arteries lesions in patients with ACS ( $p>0.05)$. Conclusion: There was no significant correlation between the levels of leukocytes and the severity of coronary arteries lesions in patients with ACS.
\end{abstract}

Keywords: leukocyte, severity of lesion, acute coronary syndrome, modified Gensini score

\begin{abstract}
Abstrak: Sindrom koroner akut (SKA) merupakan sekumpulan manifestasi atau gejala akibat penyakit arteri koroner dan trombosis yang dapat mengancam kehidupan pasien karena mengganggu pasokan darah ke otot jantung. Penilaian luas infark dilakukan dengan menilai lesi pembuluh darah koroner yang mengalami stenosis. Penelitian ini bertujuan untuk mengetahui hubungan antara kadar leukosit dengan severitas lesi pembuluh darah koroner pada pasien SKA. Jenis penelitian ialah deskriptif analitik retrospektif dengan desain potong lintang. Penilaian severitas pembuluh darah yang mengalami lesi menggunakan skor modifikasi Gensini. Hitung leukosit yang digunakan ialah saat pasien pertama kali masuk Rumah Sakit yang diperoleh dari rekam medis periode Juli-September 2015. Data dianalisis menggunakan SPSS 20.0. Hasil uji korelasi Pearson memperlihatkan tidak terdapat hubungan bermakna antara kadar leukosit dan severitas lesi pembuluh darah koroner pada pasien SKA (p $>0,05)$. Simpulan: Tidak terdapat hubungan bermakna antara kadar leukosit dan severitas lesi pembuluh darah koroner pada pasien Sindrom Koroner Akut.
\end{abstract}

Kata kunci: leukosit, severitas lesi, sindrom koroner akut, skor modifikasi Gensini

Sindrom Koroner Akut (SKA) merupakan sekumpulan manifestasi atau gejala akibat penyakit arteri koroner, yang dapat mengancam kehidupan pasien karena mengganggu pasokan darah ke otot jantung. ${ }^{1}$

Hasil Riset Kesehatan Dasar 2013 mendapatkan prevalensi jantung koroner tertinggi pada provinsi Sulawesi Tengah yaitu $0,8 \%$, diikuti provinsi Sulawesi Utara, 
DKI Jakarta, Aceh masing-masing 0,7\% dan untuk Manado sebesar 0,5\% dari 17.575 pasien. . $^{2,3}$

Jumlah leukosit dapat memrediksi angka kematian penyakit kardiovaskular aterosklerotik. Leukosit dapat menjadi prediktor dan indikator prognostik setelah kejadian iskemik dan infark miokard. ${ }^{4}$ Jumlah leukosit yang tinggi berkaitan dengan luas infark yang terjadi. Terdapat peningkatan jumlah leukosit pada pasien infark miokard akut (IMA) yang termasuk dalam spektrum SKA dan terdapat korelasi bermakna antara jumlah leukosit, Creatine Kinase (CK) atau C-Reactive Protein (CRP). ${ }^{5}$

Intervensi revaskularisasi pembuluh darah koroner perlu di lakukan pada pasien SKA. Apabila terjadi penyempitan di left main atau di 3 pembuluh darah dapat dilakukan bypass (CABG). Sedangkan apabila terjadi penyempitan di 1 atau 2 pembuluh darah dapat dilakukan PCI (Percutaneous Coronary Intervention). ${ }^{6}$

Penilaian jumlah lesi pembuluh darah koroner menggunakan kriteria dari Coronary Artery Surgery Study (CASS). Sistem skoring juga digunakan dalam penilaian severitas lesi pembuluh darah koroner termasuk skor modifikasi Gensini dari Jenkins yang dinilai dengan membagi arteri koronaria menjadi 8 segmen yaitu arteri koronaria utama kiri (left main), arteri anterior desenden kiri hingga pada mulainya cabang diagonal kedua, 1/3 proksimal cabang septal mayor dari arteri anterior desenden kiri, 1/3 proksimal cabang diagonal pertama mayor dari arteri anterior desenden kiri, arteri sirkumfleks kiri hingga mulainya cabang obtuse marginal kedua, $1 / 3$ proksimal cabang obtuse marginal pertama mayor, arteri koronaria kanan hingga pada mulainya cabang arteri desenden posterior dan 1/3 proksimal dari arteri desenden posterior. ${ }^{7,8}$

Dari studi yang dilakukan Ramadhani di RSUP Prof. Dr. R. D. Kandou Manado terhadap pasien SKA untuk melihat gambaran hematologi, didapatkan bahwa sekitar $51 \%$ pasien mengalami peningkatan jumlah leukosit pada saat diperiksa. ${ }^{9}$

\section{METODE PENELITIAN}

Jenis penelitian ini ialah deskriptif analitik retrospektif dengan desain potong lintang menggunakan data sekunder berupa rekam medis pasien SKA di Pusat Jantung dan Pembuluh darah RSUP Prof. Dr. R. D. Kandou Manado periode Juli - September 2015. Sampel dalam penelitian ini ialah pasien dengan diagnosis SKA yang datang ke RSUP Prof. Dr. R. D. Kandou Manado periode Juli - September 2015.

\section{HASIL PENELITIAN}

Dari 64 pasien SKA didapatkan terbanyak pada kelompok UAP (Unstable Angina Pectoris) yaitu sebanyak 25 orang (39\%) (Gambar 1).

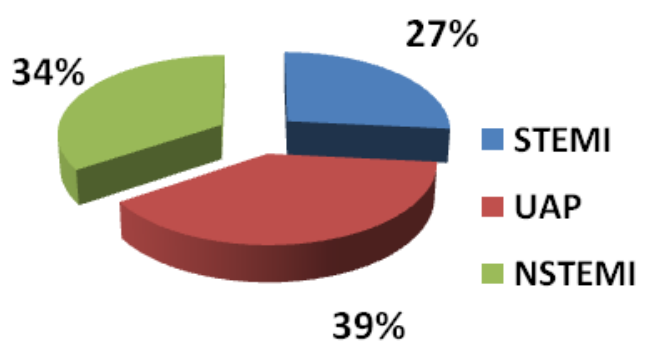

Gambar 1. Distribusi pasien berdasarkan diagnosis

Jenis kelamin laki-laki $(79,7 \%)$ lebih banyak yang menderita SKA dibandingkan dengan perempuan $(20,3 \%)$ (Tabel 1).

Tabel 1. Distribusi pasien SKA berdasarkan jenis kelamin

\begin{tabular}{ccc}
\hline Jenis kelamin & Jumlah & $(\%)$ \\
\hline Laki-laki & 51 & $79,7 \%$ \\
Perempuan & 13 & $20,3 \%$ \\
Total & 64 & $100 \%$ \\
\hline
\end{tabular}

Kelompok usia terbanyak yang menderita SKA ialah 51-65 tahun $(51,6 \%)$ (Tabel 2).

Hasil analisis data menggambarkan bahwa range leukosit terbanyak berada dalam batas normal (QI=6000$\left.10.000 / \mathrm{mm}^{3}\right)$ sebesar 34 orang dari 64 sampel (Tabel 3). 
Tabel 2. Distribusi pasien SKA berdasarkan Usia

\begin{tabular}{ccc}
\hline Usia & Jumlah & $\mathbf{( \% )}$ \\
\hline$\leq 40-50$ tahun & 8 & 12,5 \\
$51-65$ tahun & 33 & 51,6 \\
$66-75$ tahun & 17 & 26,6 \\
$76-85$ tahun & 6 & 9,4 \\
Total & 64 & 100 \\
\hline
\end{tabular}

Tabel 3. Kuartil leukosit pada pasien SKA

\begin{tabular}{ccc}
\hline Kuartil & \multicolumn{2}{c}{ SKA } \\
\cline { 2 - 3 } leukosit & Jumlah & $(\boldsymbol{\%})$ \\
\hline Q I & 34 & 53,1 \\
Q II & 28 & 43,8 \\
Q III & 2 & 3,1 \\
Q IV & 0 & 0 \\
Total & 64 & 100 \\
\hline
\end{tabular}

Pada kuartil I, pasien terbanyak ialah pasien UAP yaitu 25 orang (36\%) (Gambar 2). Jumlah pasien terbanyak berada pada total skor Gensini 0-8 (Tabel 4).

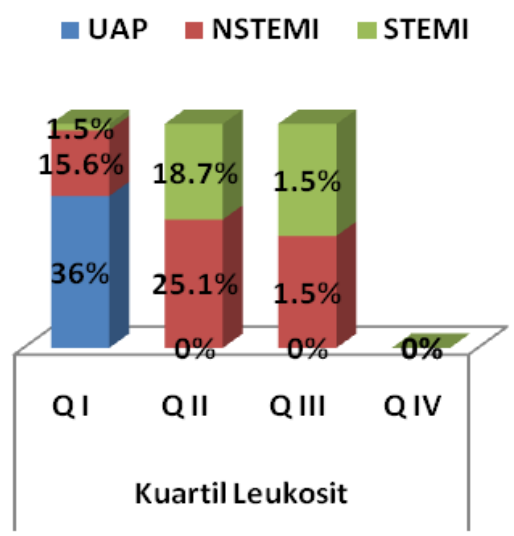

Gambar 2. Distribusi kuartil leukosit pada setiap kelompok SKA

Tabel 4. Severitas lesi dinilai dengan skor modifikasi Gensini dari Jenkins pada pasien SKA

\begin{tabular}{ccc}
\hline \multirow{2}{*}{$\begin{array}{c}\text { Severitas } \\
\text { Lesi Gensini }\end{array}$} & \multicolumn{2}{c}{ SKA } \\
\cline { 2 - 3 } & Jumlah & $\begin{array}{c}\text { Frekuensi } \\
(\boldsymbol{\%})\end{array}$ \\
\hline $0-8$ & 33 & 51,6 \\
$9-16$ & 29 & 45,3 \\
$17-24$ & 2 & 3,1 \\
$25-32$ & 0 & 0 \\
Total & 64 & 100 \\
\hline
\end{tabular}

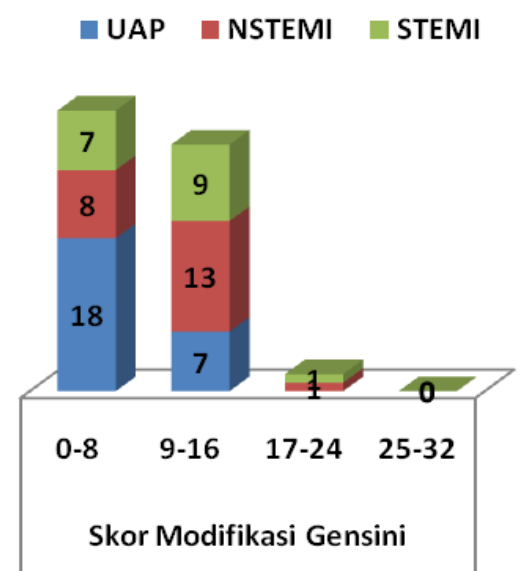

Gambar 3. Distribusi total skor modifikasi Gensini pada setiap kelompok SKA

Pada total skor 0-8 yang merupakan total skor tertinggi jumlah penderita SKA, didapatkan bahwa pasien terbanyak ialah pasien UAP. Pada Kuartil I terdapat 23 pasien dengan total skor 0-8.

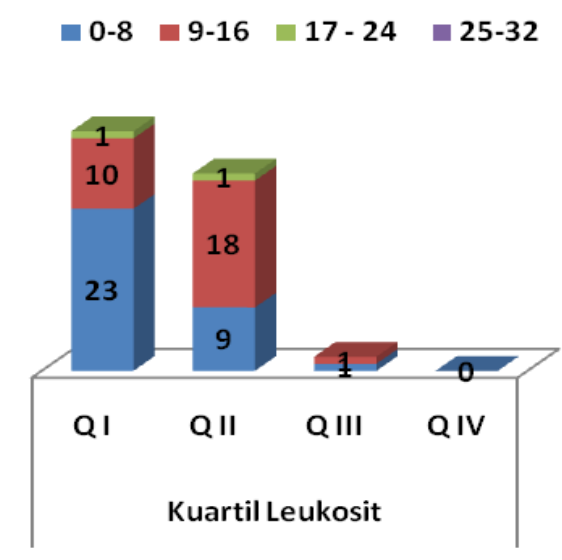

Gambar 4. Distribusi total skor modifikasi Gensini dalam setiap kuartil leukosit.

Hasil analisis korelasi memperlihatkan kekuatan korelasi sangat lemah dan juga diperoleh korelasi antara kadar leukosit dan severitas lesi pembuluh darah koroner dengan skor Gensini tidak bermakna.

Tabel 5. Hasil Analisis Korelasi Pearson

\begin{tabular}{lc}
\hline & Severitas lesi skor Gensini \\
\hline \multirow{2}{*}{ Kadar } & $\mathrm{r}=0,184$ \\
leukosit & $\mathrm{p}=0,146$ \\
& $\mathrm{n}=64$ \\
\hline
\end{tabular}




\section{BAHASAN}

Pada penelitian ini ditemukan 64 pasien SKA dengan penilaian severitas lesi pembuluh darah koroner yang dirawat di RSUP Prof. Dr. R. D. Kandou selama periode Juli-September 2015. Terdapat 17 penderita STEMI, 22 penderita NSTEMI dan 25 penderita UAP. Hal ini tidak sejalan dengan penelitian dari Torry et al. ${ }^{10}$ yang menyebutkan bahwa penderita terbanyak ialah STEMI. Hal ini mungkin disebabkan karena adanya perbedaan tempat dan waktu penelitian.

Didapatkan 51 orang dengan jenis kelamin laki-laki dan 13 orang dengan jenis kelamin perempuan. Hasil ini sesuai dengan penelitian yang dilakukan oleh Torry et al. ${ }^{10}$ bahwa penderita laki-laki lebih banyak dibandingkan perempuan. Hal ini terjadi karena jenis kelamin laki-laki merupakan faktor risiko terjadinya penyakit kardiovaskular. Jenis kelamin laki-laki dimasukan dalam faktor resiko yang tidak dapat diubah. ${ }^{10,11}$ Laki-laki lebih rentan karena faktor risiko yang ada antara lain merokok, kolesterol, dan lain-lainnya. ${ }^{12}$

Didapatkan 33 orang penderita termasuk dalam kelompok usia 51-65 tahun. Hal ini sesuai dengan penelitian yang dilakukan oleh Ramadhani et al. ${ }^{9}$ yang menyatakan kelompok usia penderita terbanyak ialah 41-60 tahun. Hal ini dikarenakan kelompok usia ini merupakan salah satu faktor risiko yang tidak dapat dimodifikasi. Pada usia 40 tahun ke bawah jarang timbul penyakit jantung koroner sedangkan pada usia 40-60 tahun, insiden SKA meningkat 5 kali lipat. ${ }^{9,10,13}$

Hasil penelitian menunjukkan bahwa kadar leukosit pasien SKA terbanyak pada kuartil I $\left(6000-10.000 / \mathrm{mm}^{3}\right)$ yaitu 34 orang. Kadar leukosit pada pasien SKA dalam batas normal. Hal ini tidak sesuai dengan penelitian yang dilakukan oleh Ramadhani et al. ${ }^{9}$ yang melaporkan bahwa pada pasien SKA terjadi peningkatan leukosit saat diperiksa.

Kadar leukosit yang normal pada sebagian besar pasien SKA mungin diakibatkan karena sebagian besar pasien SKA yang diteliti ialah pasien UAP yaitu sebanyak 25 orang. Kadar leukosit yang normal pada pasien UAP karena pada dinding pembuluh darah pasien UAP hanya terjadi denudasi, disrupsi, dan erosi dari plak, tidak terbentuk trombus dan tidak terjadi kerusakan miokard; hal ini yang mendasari sehingga kadar leukositnya berada dalam batas normal. ${ }^{14,15}$

Hasil penelitian menunjukkan bahwa jumlah terbanyak pasien SKA yang telah dinilai severitas lesi dengan menggunakan skor modifikasi Gensini dari Jenkins terbanyak pada total skor antara 0-8 yaitu 33 orang. Hal ini terjadi karena pasien terbanyak ialah pasien UAP.

Hasil analisis hubungan antara kadar leukosit dan severitas lesi pembuluh darah koroner mendapatkan nilai $\mathrm{p}>0,05$ yang menunjukkan bahwa tidak terdapat hubungan bermakna antara kadar leukosit dan severitas lesi pembuluh darah koroner yang diukur dengan skor modifikasi Gensini pada penderita SKA.

Hal ini tidak sesuai dengan hasil penelitian Madjid et al. ${ }^{16}$ terhadap pasien yang telah dilakukan angiografi pada arteri koroner yang mengalami stenosis mendapatkan bahwa neutrofil secara spesifik memiliki hubungan dengan luas, severitas dan lokasi lesi dari arteri koroner yang mengalami stenosis setelah dilakukan penilaian menggunakan indeks Gensini. Perbedaan ini terjadi mungkin disebabkan keterbatasan pada sampel penelitian dan periode penelitian. ${ }^{16}$

\section{DAFTAR PUSTAKA}

1. M Shiel WC, Stoppler C. In: Webster's New World TM Medical Dictionary (3rd ed). NewJersey: Wiley Publishing, 2008.

2. Badan Penelitian dan Pengembangan Kesehatan Kementrian RI. Hasil Riset Kesehatan Dasar (Riskesdas) 2013. Jakarta, 2013.

3. Badan Penelitian dan Pengembangan Kesehatan Kementrian RI. Riskesdas dalam angka Provinsi Sulawesi Utara 2013. Jakarta, 2013.

4. Jee SH, Park JY, Kim HS, Lee TY, Samet JM. White blood cell count and risk for all-cause, cardiovascular, and 
cancer mortality in a cohort of Koreans. Am J Epidemiol. 2005;162:1062-9.

5. Khan HA, Alhomida AS, Sobki SH, Moghairi A, Koronki H. Blood cell counts and their correlation with creatine kinase and C-reactive protein in patients with acute myocardial infarction. Int $\mathrm{J}$ Clin Exp Med. 2012;5:50-55.

6. Trisnohadi HB, Muhadi. Angina pektoris tak stabil/infark miokard akut tanpa elevasi ST. In: Setiati S, Alwi I, Sudoyo AW, Setiyohadi B, Syam AF, editors. Buku Ajar Ilmu Penyakit Dalam (6th ed). Jakarta: InternaPublishing, 2014; p. 1449-54.

7. Ringqvist I, Fisher LD, Mock M, et al. Prognostic value of angiographic indices of coronary artery disease from the Coronary Artery Surgery Study (CASS). J Clin Invest. 1983;71:1854-66.

8. Jenkins PJ, Harper RW, Nestel PJ. Severity of coronary atherosclerosis related to lipoprotein concentration. Br Med J. 1978;2:388-91.

9. Ramadhani BYS, Rotty LWA, Wantania F. Gambaran hematologi pada pasien sindrom koroner akut yang dirawat di BLU RSUP Prof. Dr. R. D. Kandou Manado tahun 2010. eBM. 2013;1:15.

10. Torry SRV, Panda AL, Ongkowijaya J.
Gambaran faktor risiko penderita sindrom koroner akut yang dirawat di RSU Bethesda Tomohon periode 1 Januari 2011-31 Desember 2012. eBM. 2014;2:4.

11. Adi PR. Pencegahan dan penatalaksanaan aterosklerosis. In: Setiati S, Alwi I, Sudoyo AW, Setiyohadi B, Syam AF, editors. Buku Ajar Ilmu Penyakit Dalam (6th ed). Jakarta: Interna Publishing, 2014; p. 1427.

12. Witt BJ, Roger VL. Population-based sex differences in disease incidence and prevalence. In: Coronary Disease in Women. New Jersey: Humana Press, 2008.

13. Brown CT. Penyakit aterosklerotik koroner. In: Price SA, Wilson LM, editors. Patofisiologi: Konsep Klinis Proses-proses Penyakit (6th ed). Jakarta: EGC, 2012; p. 576.

14. Falk E, Pradiman K, Fuster V. Coronary plaque disruption. American Heart Association. 1995;92:657-71.

15. Davies MJ. Stability and instability: Two faces of coronary atherosclerosis. American Heart Association. 1996;94:2013-20.

16. Madjid M, MD, Awan I, Willerson JT, Casscells SW. Leukocyte count and coronary heart disease. J Am Coll Cardiol. 2004;44:1946. 